\title{
The Warburg Years
}

(I9I9-I933) 
This page intentionally left blank 


\section{The Warburg Years}

$$
\text { (1919-1933) }
$$

ESSAYS ON LANGUAGE, ART, MYTH, AND TEGHNOLOGY

\section{Ernst Cassirer}

Translated and with an Introduction by S. G. Lofts with A. Calcagno

\section{Yale UNIVERSITY PRESS}

New Haven and London 
Published with assistance from the Ernst Cassirer Publications Fund, and from the foundation established in memory of Philip Hamilton McMillan of the Class of 1894, Yale College.

Copyright (C) 2013 by Yale University.

All rights reserved.

This book may not be reproduced, in whole or in part, including illustrations, in any form (beyond that copying permitted by Sections Io7 and 108 of the U.S. Copyright Law and except by reviewers for the public press), without written permission from the publishers.

Yale University Press books may be purchased in quantity for educational, business, or promotional use. For information, please e-mailsales.press@yale.edu (U.S. office) or sales@yaleup.co.uk (U.K. office).

Set in Baskerville type by Integrated Publishing Solutions. Printed in the United States of America.

Library of Congress Cataloging-in-Publication Data

Cassirer, Ernst, I874-1945.

[Essays. Selections. English]

The Warburg years (1919-1933) : essays on language, art, myth, and technology / Ernst Cassirer ; translated and with an introduction by

S.G. Lofts with A. Calcagno.

pages $\mathrm{cm}$

Includes bibliographical references and index.

ISBN 978-0-300-Io8I9-4 (cloth : alk. paper) I. Philosophy,

German - 2oth century I. Title.

$\mathrm{B}_{321} 6 . \mathrm{C}_{32} \mathrm{E}_{5} \quad 2013$

I93 - de23 201301580I

A catalogue record for this book is available from the British Library.

This paper meets the requirements of ANSI/NISO Z $39 \cdot 48^{-1992}$

(Permanence of Paper).

Io 98765432 I 
To John Michael Krois 
This page intentionally left blank 